DOI: https://doi.org/10.47631/jareas.v2i3.288

\title{
Sustainability in Fleet Management
}

\author{
Prof. Erkut Akkartal ${ }^{1}$, G. Yiğit Aras ${ }^{2}$ \\ ${ }^{1}$ Professor, Faculty of Commerce, Yeditepe University, \\ ${ }^{2}$ Ph.D. Student in Political Economy, Yeditepe University
}

\begin{tabular}{|c|c|}
\hline Article Info & Abstract \\
\hline $\begin{array}{l}\text { Article history: } \\
\text { Received:11June } 2021 \\
\text { Revised: } 18 \text { August } 2021 \\
\text { Accepted: } 22 \text { August } 2021\end{array}$ & $\begin{array}{l}\text { Purpose: This paper aims to discuss sustainability in fleet management at } \\
\text { companies considering simultaneously the three dimensions of sustainability, } \\
\text { which are economic, environmental, and social, corresponding to the Triple } \\
\text { Bottom Line (TBL) approach. }\end{array}$ \\
\hline Keywords: & $\begin{array}{l}\text { Approach/Methodology/Design: This paper examines the subject and } \\
\text { employs a theory-building-descriptive design. Three key themes in the aspect } \\
\text { of sustainability and in terms of fleet management were examined: economic, }\end{array}$ \\
\hline Sustainability & environmental, and social. \\
\hline Fleet Management & Findings: In today's world, almost every company operates vehicle fleets to \\
\hline The TBL Approach & perform business requirements and irrespective of the size of vehicles, these \\
\hline The Mobility of Things & companies need to execute some certain fleet operations under the \\
\hline $\begin{array}{l}\text { The Total Cost of Mobility } \\
\text { (TCM) }\end{array}$ & $\begin{array}{l}\text { phenomenon of fleet management. Fleet management entails a transition to a } \\
\text { more sustainable model which should try to adopt economic, environmental, } \\
\text { social dimensions. While the economic dimension of sustainability brings }\end{array}$ \\
\hline JEL: R41, R42, M10 & $\begin{array}{l}\text { about a new model called the TCM, the environmental dimension constructs a } \\
\text { road map to greener fleets and delivers quick wins that companies can easily }\end{array}$ \\
\hline Paper Type : & implement in their agendas. The social dimension concerns the well-being of \\
\hline Research Article & $\begin{array}{l}\text { people and society which seeks to find a balance between their needs and the } \\
\text { requirements of fleet management. }\end{array}$ \\
\hline Corresponding Author: & $\begin{array}{l}\text { Practical Implications: The paper recommends a subsequent study through } \\
\text { an empirical way that would investigate the actual sustainability behaviours }\end{array}$ \\
\hline G. Yiğit Aras & $\begin{array}{l}\text { and initiatives of companies present in Turkey. } \\
\text { Originality/value: In recent years, sustainability has become an interesting }\end{array}$ \\
\hline ORCID ID: 0000-0002-0187-0118 & $\begin{array}{l}\text { topic for scholars in many areas of research. However, the literature is } \\
\text { lacking ample studies concerning sustainability in corporate fleet }\end{array}$ \\
\hline $\begin{array}{l}\text { Email: } \\
\text { garipyigit.aras@std.yeditepe.edu.tr }\end{array}$ & $\begin{array}{l}\text { management. Therefore, the main contribution and novelty of this paper is to } \\
\text { provide companies with policy advice regarding the three pillars of } \\
\text { sustainability for their applications to vehicle fleet management. }\end{array}$ \\
\hline
\end{tabular}

\section{Introduction}

Sustainability as a concept took its roots in 1987 and proposed by the World Commission on Environment and Development (WECD) (Singh, Gurtu, \& Singh, 2020). In this initial definition, the emphasis was put on the continuity of and responsibly use of the environmental and natural resources while considering the forthcoming generations (Küçükoğlu \& Pınar, 2018). Over the years, this definition has also extended to cover social and economic aspects of business life. As the economy exists for meeting the increasing needs of people and are reflecting the cultural aspects of a society, an economy belongs to its society that therefore is part of an ecological environment. Hence, they are interdependent and interrelated with each other (Nunes \& Bennet, 2010).

A common way of interpreting sustainability is through the 'Triple Bottom Line (TBL) 
approach. Since the environment, society and economy are also intertwined with the planet, people and profit, the concept of sustainability can be well assessed by the TBL. In the same manner, from a company perspective, sustainability can also embrace environmental, social, and economic practices (Küçükoğlu \& Pınar, 2018) and the result of business operations in terms of financial performance is also attached to social and environmental performance (Azevedo \& Barros, 2017). Thus, companies need to take the sustainability issue as part of their daily business (Labuschagne, Brent, \& van Erck, 2005) and should need to consider their success not only with financial performances but in the TBL context of sustainability (Tokgöz \& Önce, 2009).

Sustainability decisions from the TBL approach that seeks to find a balance between economic, environmental, and social can also be attributed to the transportation sector and, more specifically, to companies which choose to use cars and vans extensively or any modes of transportation (Goldman \& Gorham, 2006). From pharmaceuticals to IT companies, from manufacturing \& construction companies to the public sector, from retail to financial services and to many others, every company from almost every business sector and for any reason need and prefer to be mobile which requires them to perform a set of certain fleet management activities. Accordingly, managing a fleet in terms of these three-pillars of sustainability is gaining considerable importance in a world of changing mobility. Economic sustainability, for example, could involve if the primary aspects of transportation on cost, time and quality are met. Environmental sustainability might include whether it can respond to the national and regional environmental regulations if it can meet the emission standards or whether it can reduce the use of non-renewable resources and help accelerate the management of the recovery of scrap. Social sustainability can ensure the importance of transportation security while reducing deadly accidents and creating less social noise (Bai, Fahimnia, \& Sarkis, 2017).

This paper wants to be an early attempt in the context of TBL and aims to bring a novelty to the literature keeping the sustainability issue in the perspectives of economic, environmental, and social at the core while addressing their inclusion in company fleet management. Literature covers a considerable number of papers that show interest in the problems of fleet management. Among these, for example, there are heterogenous vehicle routing problems, fleet composition problems, vehicle routing and scheduling problems related to private and public urban transport, dial-a-ride transport, and specific problems related to air, maritime, rail and intermodal transport (Monnerat, Dias, \& João Alves, 2019). A few papers give attention to the fleet management problems in car rental companies which is however not plentiful in the literature (Beatriz, Maria, \& José, 2016). Even though a sizable body of articles focus on the impact of electric mobility on transport sector mobility (Foggia, 2021), this does not mainly relate to the company fleet management. The initiatives of sustainability can, on the other hand, take in the form of sustainable supplier selection, sustainable supply chain management, sustainable manufacturing and service provision, and sustainable information technology (Bai, Fahimnia, \& Sarkis, 2017). To the best of my knowledge, sustainability in the sphere of fleet management at corporate levels has not yet much attracted researchers and the literature is lacking ample studies on this topic. The contribution of this work, therefore, is to provide companies with policy advice on sustainability issues in their applications to vehicle fleet management.

Copyright (C) 2020, Journal of Advanced Research in Economics and Administrative Sciences (JAREAS), Under a Creative Commons Attribution 4.0 International License 
For whatever the reasons, companies need a fleet of cars and/or vans (hereafter collectively named as the "vehicles") as part of road transportation, where the term fleet corresponds to at least of two vehicles in operation, and that they can be acquired employing various types such as direct ownership, operating or finance leasing and short-term car rental. An orthodox way of describing fleet management in a company should include a set of certain activities related to the vehicles including but not limited to vehicle procurement, financing, payrolling, tax management, maintenance, tyre replacement, and disposal, that a company performs for a predetermined period, either internally through a dedicated fleet manager who coordinates the activities centrally, or via outsourcing of such activities to a fleet management company with an attempt to reduce costs and create efficiencies. This traditional definition provides a variety of considerations in the uptake of and implementing the proper way of managing a fleet of vehicles but perhaps the salient one is regarding how vehicles are running on costs perspectives. Fleet costs that are widely referred to by companies and business professionals to as the Total Cost of Ownership (TCO), which is an estimate that incorporates both the explicit (direct) and implicit (indirect) costs into the calculation. Direct costs can be comprised of acquisition and financing, insurance, maintenance and repairs, and the management of tyres such as replacement ad storagewhereas indirect costs can arise from the foregone opportunity of the next best alternative, downtime, and idle time of vehicles. Hence, TCO analysis delivers a cost basis to arrive at the economic value of vehicles (Fleet Forum, 2019). The TCO concept can purely address the economic sustainability of fleet management whilst ignoring other pillars.

In contrast, according to this paper, fleet management is a much broader notion that can be conceived as a technology-centric and flexible end-to-end process that is to grant the 'mobility of things' in providing them with eco-friendly and hassle-free modes of transportation while taking care of their safety and health, and to create value for the company by optimizing costs and with an aim to contribute to the overall company image that is appreciated by the key stakeholders. The need for giving a new and conceptualized definition pertaining to the fleet management has been by virtue of some considerable factors. Among these factors, an important one is a change in mobility requirements of companies and their drivers which have been outgrown amid COVID-19. This has increased the demand for the micro-mobility solutions and its variances, such as (e)-bikes, (e)-scooters, and even short distance walking to get to destinations, which has become almost a necessity for life especially in densely populated cities like Tokyo, Delhi, Shanghai and İstanbul. Another good reason is due to the continuous pressure from the governments in accordance with L'accord de Paris (the Paris Agreement) to the global auto industry to manufacture more environmentally friendly and fuel-efficient vehicles like Battery Electric Vehicles (BEV's) or Plug-in Hybrids (hereafter collectively named as EV's).

By this definition, the TCO turns into a contemporary form where the new definition has produced the Total Cost of Mobility (TCM) concept. In addition, within the concept of TCM, thought of the mobility of things is an important one as that encapsulates the conveyance of people, their belongings, or the goods and produces of companies that is performed with the most economically optimum and efficient way and in a manner of socially responsive and environmentally friendly. Consequently, the TCM, as opposed to the TCO, addresses the 3 pillars of sustainability in fleet management so, it serves this end.

Copyright (C) 2020, Journal of Advanced Research in Economics and Administrative Sciences (JAREAS), Under a 
The remainder of this paper is organized as follows: Section 2 reviews the most relevant literature to this study. Section 3 introduces fleet management and addresses the three pillars; And last, Section 4 presents the conclusions and proposes a further area of investigation.

\section{Literature Review}

For the last few years, the subject of sustainable development has taken on increased importance in society and business (Schöggl, Baumgartner, \& Dietmar, 2016). In 1987, The United Nations World Commission on the Environment and Development defines the sustainable development as "meeting the needs of the present without compromising the ability of future generations to meet their own needs". This definition is generally addressed to the environmental sustainability putting an emphasis on protection of natural resources and the environment (Grayson \& Kjelleren, 2015). In this respect, the transport sector is the biggest contributor to climate change among all where the road transport itself is responsible for around $20 \%$ of all $\mathrm{CO} 2$ emissions in the Europe and approximately a third of greenhouse gas emissions in the USA (LeasePlan, 2017). However, it is not only about the environmentalism and the term is also embedded in the definitions of sustainability for the concerns of economic and social (McGill, 2013). In agreement with the so-called 'the triple bottom line' concept as a way to approach the phenomenon of sustainability, there are three performance dimensions found in the literature (Nunes \& Bennet, 2010) These are the Environmental, Social, and Economic dimensions that equivalent importance needs to be given to each of them when companies make strategic business and policy decisions (Teresa, Ferreira, Silva, \& Tjahjonoc, 2020).

In recent years, the road transport has become one of the focus areas related to sustainability (Chiara \& Pellicelli, 2016) and there are two definitions given to the sustainable transport. The first one is attributed to the environmental problems and depletion of natural resources. As (May, Page, \& Hull, 2008) assert that sustainable transportation should provide us with neat and clean streets, protection for the environment and be of support to a living economy. The second definition considers social and economic welfare (Litman \& Burwell, 2006). With a holistic consideration of the definition, a sustainable transport system must create to beneficiaries of mobility and accessibility in an environmentally friendly way which is a complex objective as it requires to contemplate the needs and demands of people who base decisions on the factors such that economic, convenience, comfort, and safety (Singh, Gurtu, \& Singh, 2020). Therefore, it is of great importance and as well as challenging when the assessment of and deciding upon the appropriate transportation vehicle when the traditional economic models are in focus and subject to the sustainability considerations. At first, it commences with finding out and, as a next step, evaluating the associated aspects of sustainability. What comes next is setting objectives for economic, social, and environmental concerns and to find a balance within them. Consequently, organizations should ensure that they neatly measure the transport fleet requirements provided that their economic goals, environmental and social sustainability strategies are maintained (Bai, Fahimnia, \& Sarkis, 2017).

Companies are moving from the standalone economical oriented view and having transition to a more sustainable business model while trying to adopt environmental, social, and economic focus in their operations (Azevedo \& Barros, 2017). This is happening because there are internal

Copyright (C) 2020, Journal of Advanced Research in Economics and Administrative Sciences (JAREAS), Under a Creative Commons Attribution 4.0 International License 
and external factors are playing an important role why companies are to adopt these practices. Pressures from governments, laws, policy makers, shareholders, society, customers, suppliers, and some other micro-level factors are the salient of those influencers (Küçükoğlu \& Pınar, 2018).

\section{Factors Affecting the Decisions of Sustainability}

Literature has identified various factors why companies implement sustainability innovations (Hermundsdottir \& Aspelund, 2021). In this context, (Diaz-Garcia, Gonzales-Moreno, \& SaezMartinez, 2015) and (Hart \& Milstein, 2003) \& (Rodrigo, 2015) claim that there are two factors that accelerate companies to take these practices. These factors are called external and internal pressures. Internal factors cover, for example, financial resources, knowledge and expertise, infrastructure, (Law \& Gunasekaran, 2012) and according to (Rodrigo, 2015) these also include proactive leadership, business case, and company's culture.

External pressures, on the other hand, could stem from several sources and one of them is due to customers (Szasz, Csiki, \& Racz, 2021). Based on the study conducted by (Chiou, Chan, Sai, \& Chung, 2011), for customers green products are becoming more important every day and they ask for the green products from companies which gives motivation for firms to implement new eco-friendly and innovative production processes to end up with more sustainable products advantage (Reinhardt, 1998) \& (Zhou, Brown, \& Dev, 2009). The market demand for green product urges companies to take on sustainability practices (Wei \& Morgan, 2004). (Hetterich, Bonnemeier, Pritzke, \& Georgiadis, 2012) in their study for the automotive market as an example claim that customers of the car market are willing to buy more environmentally sustainable products for which they are also ready to spend more when their cars fit with more renewable materials and accessories. In Tesla case, for instance, the luxury is also making a move in the sustainability direction because the customers showing interest in its products and demand cars where there is also a social pressure to act sustainable (Aybalya, Laura, Manierea, Madacovaa, \& van Holt, 2017). Furthermore, (Henriques \& Sadorsky, 1996) noted that pressures from customers are the main contributing factor for firms to adopt environmental plans while (Thun \& Müller, 2010) in their survey in Germany assert that customers are the leading reason why companies are taking eco-friendly initiatives. Finally, (Zhu, Sarkis, \& Lai, 2013) emphasize that the companies have been forced by customers to implement and maintain internal eco-design initiatives. In an empirical study, (Ateş, Bloemhof, van Raaij, \& Wynstra, 2011) validated the relationship between customer pressure and both internal and external environmental investments.

Suppliers are the second factor that put pressure on the companies to adopt sustainable innovation practices (Szasz, Csiki, \& Racz, 2021). A collaborative external relationship with suppliers helps companies take on and develop fruitful internal environmental technologies, which means environmental practices affect internal initiatives and therefore, it further improves the company performance (Zhu, Sarkis, \& Lai, 2013). (Turker \& Altuntaş, 2014) showed when companies start considering their suppliers as the strategic partners and aim at establishing longterm objectives with them, then they tend to use common standards and environmental procedures to implement sustainability issues. Also, according to (Gavronski, Klassen, Vachon,

Copyright (C) 2020, Journal of Advanced Research in Economics and Administrative Sciences (JAREAS), Under a Creative Commons Attribution 4.0 International License 
\& Nascimento, 2011) internally adopted green manufacturing processes can make a higher-order supplier collaboration which can derive from a distinctive combination of capabilities. In addition to that, companies can benefit from the green product and process innovation as these factors contribute to companies' environmental performance and their competitive advantage (Chen, Lai, \& Wen, 2006). If these green initiatives are also implemented by the suppliers in the supply chain, then the environmental performance will be further achieved (Chithambaranathan, Subramanian, Gunasekaran, \& Palaniappan, 2015). Last but not least, if the suppliers adopt sustainability practices, such practices will enhance the product innovation which will provide companies with an improved environmental performance and hence the competitive advantage (Chiou, Chan, Sai, \& Chung, 2011).

The third type of pressure can come from the governments, laws, regulation, and the penalty systems which are forcing companies and manufacturers to reduce the negative environmental impacts of cars (Elmquist \& Segrestin, 2009) In the recent years, automotive companies have faced with more stringent sanctions imposed by governments that are pushing them to look for and implement more sustainable operations. In addition, papers in the literature contend that legal and regulatory pressures are the most important external drivers for companies to give more attention to the sustainability-centric strategies (Szasz, Csiki, \& Racz, 2021). In their paper (Zhu, Sarkis, \& Lai, 2013) explained that manufacturers as being the greater polluters than others are subject to greater pressure and, in another paper, (Hsu, Tan, Zailani, \& Jayaraman, 2013) stated that manufacturers in Malaysia were forced to have more environmentally friendly operations and this was made by the institutional forces. Furthermore, a study based in China showed that manufacturers were faced to become more sustainable by institutional pressures and found that regulatory forces are the primary factors for the companies to implement green supply chain practices (Zhu, Sarkis, \& Lai, 2013). Moreover, car makers must not only comply with the constraints of international organisations and local governments but also with the pressure which has arisen from the civil society as well (Chiara \& Pellicelli, 2016). (Nakamura, Takahashi, \& Vertinsky, 2001) contributed to this by explaining that beside governmental regulations, nongovernmental organizations force automotive companies to adopt sustainability practices.

As a result, increasing emphasis put on the topic of sustainability has been not only due to the environmental issues, such as $\mathrm{CO} 2$ emissions and other types of pollution, but also some other key factors such as government regulations, changing customer needs, health, and safety issues which have induced companies to consider sustainability initiatives with greater attention (Marchet, Melacini, \& Perotti, 2014). Thus, companies need to contemplate all dimensions of sustainability. This can be achieved while aiming to minimize, or preferably prevent, undesirable and negative effects of their actions on the environment and at the same time by giving a thorough consideration on the social aspects of these decisions and actions in a way that the business remain its profitability (Hermundsdottir \& Aspelund, 2021).

Copyright (C) 2020, Journal of Advanced Research in Economics and Administrative Sciences (JAREAS), Under a Creative Commons Attribution 4.0 International License 


\section{Results and Discussion}

\section{Fleet Management and the Three Pillars}

This section is comprised of 4 subsections. At first, the definition of fleet management and its scope for companies will be discussed. Next, the economic, environmental, and social pillars of sustainability within the context of company fleet management will separately be addressed and each separate subsection aims to furnish companies with a policy advice towards its application.

\section{The Concept of Fleet Management}

In his seminal article of 1953, Mr. T.L. Preble ${ }^{1}$ presented the scope of fleet management which was indeed one of the earliest attempts in this area. According to him, the purpose fleet management should encompass the reduction of capital expenditure and operational expenses, and facilitation of executive supervision. Also, he asserted that equipment selection and disposal (what he calls this as retirement), field job analysis and cost accounting, maintenance, and vehicle operating techniques aimed to decrease amounts paid in cash and investment expenditures are the extents that fleet management is to achieve (Preble, 1953).

Contemporary definition of fleet management goes quite in parallel of what was proposed by Mr. Preble in his article of 1953. Fleet management can, in general terms, be defined as the activities that starts from planning, budgeting to vehicle acquisition and then through to vehicle disposal. In between, there are operational tasks exist. Management of maintenance and repairs; tyre changes, renewal and storing; taxes management; inspections; fuel management; driver related duties such as licence checks; insurance and accident management; and reporting are the most important of those that first come to mind. Fleet management activities can be performed within companies, mostly by a dedicated person, usually called the fleet manager/executive/responsible or outsourced to an external fleet management company which provides solutions over the whole life cycle of a vehicle in a pre-determined contract. In any type of sourcing, the centralised operations and control presents important advantages. For example, centralized purchase contracts on volume basis through bulk quantities correspond to higher discounts and savings. Standardization of service policies and dealer procedures, as another example, can eliminate unnecessary overhead costs.

A fleet can encompass cars, trucks, vans, e-vehicles, or some combination of them. In today's world, almost every company operate fleet vehicles include, for instance, pharmaceuticals, IT companies, food and beverage companies, delivery services, manufacturing companies, other service providers and even governments and local authorities.

\footnotetext{
${ }^{1}$ I greatly appreciate the genius of Mr. Preble ${ }^{\mathrm{i}}$ and his influential work on fleet management. To the best of my knowledge, this is the earliest work and the one which sheds lights on today's fleet management sector. His propositions on the scope of fleet management and analytical approach well deserves recognition and respect. Considering the fact that the foundation of today's professional fleet management companies ${ }^{\text {ii }}$ date back to early 1960 's, his article on fleet management is very thorough and comprehensive that could be seen to be the gospel of fleet management in the literature. Before his that article, he had also written another one about the problems of the motor-transportation executive in 1930.

${ }^{i}$ T.L. Preble was a supervisor of Automotive Transportation for the Tide Water Associated Oil Company who started to work there in 1934. Mr. Preble graduated from the University of California and took an active service overseas in World War I for the U.S. He also served as consultant to the War Department during the World War II and also took an active duty as a Colonel in the Ordnance Department.

Source: Fleet Management: A Job Evaluation, 1953, Vol. 61, p.273

ii LeasePlan was one of the earliest vehicle leasing companies which was founded in 1963; ALD's roots was beginning in 1958 but officially founded in 1968; and Arval was founded in 1989.
}

Copyright (C) 2020, Journal of Advanced Research in Economics and Administrative Sciences (JAREAS), Under a 
Irrespective of the size of fleet vehicles, companies need to carry out some certain fleet operations when vehicles are running on the road and the overview of these services, not limited to this list, can be summarised as below:

- Maintenance and repairs management: Organizing maintenance and repairs of vehicles compliant with manufacturer advised maintenance intervals so that vehicles can continue on the road in the best conditions.

- Tyre replacement: Organizing tyre replacement including ordering and administrative handling.

- Driver assistance: Direct contact, when required, between vehicle drivers and the fleet manager.

- Replacement vehicles: Managing all activities related to the provision of a replacement vehicle, when needed, to ensure permanent mobility of drivers.

- Accident management: In case of an accident, coordinating all communications between the driver and insurance company, and recovery agent. It is a process to put the vehicle back on the road as quickly and cost effectively as possible.

- Insurance management: Handling all aspects of running vehicle insurance, including negotiation, payment, and administrative handling of the insurance of all types (i.e., casco, traffic, third-party liability and etc.) that is relevant to fleet vehicles.

- Road assistance: Coordinating break-down assistance in case the vehicle breaks down or is involved in an accident.

- Other services: Toll management, reporting, fines managements, fuel management, taxes management, mandatory vehicle inspections, short-term car rentals are to name but a few.

Historically, companies preferred ownership of their fleet vehicles and have managed their fleets within the business. Over the last years, this has changed considerably, and more and more companies have turned to full-service leasing contracts in an attempt to reduce fixed assets and to avoid residual value risks. In addition, more and more companies have outsourced their fleets to companies that are specialised in this field to achieve cost reductions (Deloitte, 2017). Rapid changes in business environment further forces companies to look for alternative mobility options that would allow them greater driver convenience and contract flexibility. As a response to this, fleet management companies, with advances in technology, have started to investigate multimodal mobility options for their corporate clients. In an exclusive interview made by Fleet Europe with Yaël Bennathan, Head of the Arval Mobility Observatory, it is exerted that no less than $71 \%$ of companies have already implemented alternative mobility solutions for their employees, especially in the Netherlands, Switzerland, and Brazil. There are several types of solutions among all have made great improvements are mobility budgets, from $14 \%$ in 2020 to $29 \%$ in 2021, and corporate car-sharing, from 19\% in 2020 to $28 \%$ in 2021, (Frank Jacobs, 2021). Philips, for example, have implemented the offerings of alternative and innovative mobility modes next to the company car which brings together initiatives like the mobility card, carsharing, ride-hailing, on-demand shuttle services and e-biking to optimise flexibility and sustainability while giving an emphasis on stakeholder and employee satisfaction (Benjamin Uyttebroeck, 2020). In the future, fleet management companies are more and more demanded and expected to be the providers of multimodal mobility services that companies can cooperate with their fleet management activities.

It will always be important for companies to understand their organizational goals and aligning them with driver and fleet requirements that will be vital for fleet operation's success.

Copyright (C) 2020, Journal of Advanced Research in Economics and Administrative Sciences (JAREAS), Under a 


\section{Economic Sustainability in Fleet Management}

A company's decision to operate a vehicle is mainly driven by the economic/financial factors. Economic state of a company can shape what method of acquisition will be selected and implemented throughout the vehicle life-cycle. Among all, the most popular and common methods for obtaining corporate fleets are operational leasing, financial leasing, and outright purchase. Considering the fact that each of these requires different performance measures and thought process, the cost perspective of fleet management brings about a common understanding within the three methods - the Total Cost of Ownership (TCO $)^{2}$. The total cost of ownership is the most common and conventional way of identifying cost saving potential and reducing operational costs (Deloitte, 2017). It defines the cost of owning a vehicle from the time that is purchased, through its cost of operations to the moment it is disposed. It is a one employee-one car model that from a behavioural standpoint, vehicle users act as owners of the vehicle rather than as users of the vehicles (FleetEurope, 2021).

In one of the most conventional TCO analysis, companies in general put together all information they have known about fleet management and make a comparison between leasing and purchasing. This analysis is usually seen as comfort analysis by companies since it can provide companies with a good initial understanding of actual vehicle costs in terms of their TCO and help companies build up their business case for change. The results of such an analysis should be treated company specific. It could not be possible and correct to infer that the outcome always yields the same indications for the market as it can vary between companies concerning the internal and external factors they might face. For example, in case of purchasing, a logistics company with a fleet of +100 vehicles is expected to have much better terms in procurement of a vehicle compared to a small-medium enterprise (SME) which operates in tourism business that runs a fleet of 5 vehicles. Also, the same logistics company would perform better than the SME in managing their operational costs when discounts in maintenance and repairs, tyres, and other similar services are taken into consideration, plus the expertise that the logistics company already excels in fleet management. Again, when the same companies are considered, another discrepancy can emerge from the easiness to access to cheaper costs for financing or relatively low credit rates as the logistics company might be working with a solid, loyal, and strong customer base with a high payment performance compared to the case with the SME which cannot regularly increase its sales and cannot sustain the business profitability.

\section{Lease vs. Buy Analysis}

In order to demonstrate an example of a lease vs. buy analysis, we need some assumptions to make the analysis straightforward. First, assume that company $X$ is an abstract company established in Turkey and interested in leasing vehicles for its employees. Company $\mathrm{X}$ is a respected one and easily reach out to commercial credits of any type from financial institutions and banks. Second, since it is the board decision, company $\mathrm{X}$ does not prefer using its retained earnings as a source of financing of its vehicles hence, it decides to take out a loan. Let's assume

\footnotetext{
2 TCO is applicable to any method as the only difference would matter how a company reaches out the sum of all expenses relevant to the cost calculation. For example, if a company directly purchases a car rather than contracting it from a leasing company, then it is not expected to pay a fee or commission to leasing company for managing its vehicles throughout the agreed period. On the other hand, the same company would need to employ a fleet manager or dedicate an employee to take care of the fleet of vehicles. In such a case, management fee is not part of the TCO calculation but the amount of direct labour embodied needs to be considered as an expense.
}

Copyright (C) 2020, Journal of Advanced Research in Economics and Administrative Sciences (JAREAS), Under a 
that the cost of borrowing is $19 \%^{3}$ and is the same for both the company $\mathrm{X}$ and a leasing company, named the supplier, based in Turkey too that manages a fleet of $+10,000$ vehicles contracted with various companies in many sectors. Third, further assume that company $\mathrm{X}$ and the supplier have the same level of fleet management knowledge and the same technology in terms of operating fleet vehicles is used by both company $\mathrm{X}$ and the supplier. Therefore, company $\mathrm{X}$ do not need extra investments than to follow the routines. Fourth, company X's vehicle drivers are benevolent and altruistic employees and not receiving a central inhouse operational support from a dedicated fleet manager for running their cars on road, but the company pays out to the supplier a management fee of $100 \mathrm{TL}$ per/car in any case (i.e., leasing and purchasing) for maintaining the hotline services ${ }^{4}$ to its drivers. Fifth, company $\mathrm{X}$ and the supplier have the same remarketing network that vehicles can be sold for without paying any extra fees and both can appropriate for the same residual value (i.e., a vehicle's second hand value). And lastly, the inflationary price effect on service costs and the residual value is excluded from the analysis for the sake of easiness.

Based on the above assumptions, a lease vs. buy analysis can be estimated and an example is herewith presented below.

Table 1: Lease vs. Buy Analysis

\begin{tabular}{|c|c|c|c|}
\hline Section I & Vehicle Specifications & Definition & \\
\hline \multirow{13}{*}{$\begin{array}{l}\text { LEASE VS. BUY } \\
\text { ANALYSIS }\end{array}$} & Make & Toyota & \\
\hline & Model & Corolla & \\
\hline & Type & Hybrid & \\
\hline & Gear Type & Automatic & \\
\hline & \begin{tabular}{|l} 
Vehicle Price Specifications \\
\end{tabular} & & \\
\hline & List Price (including all taxes and VAT) & $€ 329.150$ & \\
\hline & Discounted Price as an Investment Value & $€ 315.000$ & \\
\hline & Leasing Specifics & & \\
\hline & Monthly Leasing Cost & $€ 6.432$ & \\
\hline & Lease Duration (in months) & 36 & \\
\hline & Contractual Mileage & 90.000 & \\
\hline & Cost of Borrowing & & \\
\hline & Average Commercial Credit Rate (Annual) & $19 \%$ & \\
\hline Section II & Description $^{5}$ & Buying on Loan & $\begin{array}{c}\text { Full } \\
\text { Operating } \\
\text { Leasing }\end{array}$ \\
\hline Frequency & Cost and Revenue Items & & \\
\hline One time & Investment Value & も315.000 & - \\
\hline $\begin{array}{l}\text { In total of } 36 \\
\text { months }\end{array}$ & Periodic Maintenance and Repair & €7.414 & - \\
\hline
\end{tabular}

3 The cost of borrowing is calculated by taking the average of commercial credit rates from 2017 to 2020 in December of each respective year. The last month's commercial credit rates were 17,06\% (2017), 27,04\% (2018), $12,02 \%$ (2019) and 19,62\% (2020).

Source: https://evds2.tcmb.gov.tr/index.php?/evds/dashboard/341

${ }^{4}$ This is a crucial assumption as the fleet management is, in general and in both cases, performed by a dedicated employee who can fully or partially be responsible for taking care of the company's fleet. In that sense, a dedicated employee's salary is the direct cost that needs to be added upon total service costs in case a company chooses to buy. Each company's decision on how to allocate the necessary resource to perform this task is at its own discretion and now creates ambiguity so, for simplicity of this analysis it is assumed to be an excluded variable.

${ }^{5}$ VAT of $18 \%$ is included in the investment value. Other costs do not include the value-added tax, where applicable. 


\begin{tabular}{|c|c|c|c|}
\hline $\begin{array}{l}\text { In total of } 36 \\
\text { months }\end{array}$ & Tyre Changes $x$ all tyres and twice & $€ 7.320$ & - \\
\hline $\begin{array}{l}\text { In total of } 36 \\
\text { months }\end{array}$ & $\begin{array}{l}\text { Total Insurance Costs - including casco, TPL and } \\
\text { mandatory insurances }\end{array}$ & も22.274 & - \\
\hline $\begin{array}{l}\text { In total of } 36 \\
\text { months }\end{array}$ & Road Tax & も10.920 & - \\
\hline $\begin{array}{l}\text { In total of } 36 \\
\text { months }\end{array}$ & $\begin{array}{l}\text { Management Fee - based on the assumption } \\
\text { of fourth }\end{array}$ & $€ 3.600$ & \\
\hline One time & $\begin{array}{l}\text { Residual Value - estimated resale value after } \\
36 \text { months ( } 3 \text { years) }\end{array}$ & $€ 253.446$ & - \\
\hline $\begin{array}{l}\text { In total of } 36 \\
\text { months }\end{array}$ & Cost of Interest & €164.138 & - \\
\hline Monthly & Cost of Leasing - from the supplier & - & $€ 6.432$ \\
\hline Section III & \multirow[t]{2}{*}{ Total Cost of } & Buying on Loan & $\begin{array}{c}\text { Full } \\
\text { Operating } \\
\text { Leasing }\end{array}$ \\
\hline $\begin{array}{l}\text { In total of } 36 \\
\text { months }\end{array}$ & & $€ 277.220$ & $€ 231.552$ \\
\hline \multirow[t]{2}{*}{ One time } & Corporate Tax Rate - applicable rate in 2021 & $25 \%$ & $25 \%$ \\
\hline & Tax Benefit & $€ 69.305$ & $€ 57.888$ \\
\hline Section IV & ESTIMATED NET RESULT - in terms of costs & $€ 207.915$ & Ł173.664 \\
\hline
\end{tabular}

Table 1 illustrates a traditional lease vs. buy analysis for a $\mathrm{C}$ segment vehicle - in this case, it is Toyota Corolla Hybrid. When company X wants to buy the car on loan, it will pay an initial outlay to a dealer amounting $315,000 \mathrm{TL}$ accrued as investment cost. This is the amount that company $\mathrm{X}$ would likely be advised by the dealer of Toyota, and it reflects a fleet discounts determined by the car manufacturer. Compared to the supplier, company $\mathrm{X}$ has relatively small discounts that is applied to the vehicle's list price. This means, the supplier has a comparative advantage in purchasing price of the same vehicle which arises from strong purchasing powers due to high order quantities. Also, it implies that the higher the discount rate applied, the lower the cost of investment of a vehicle. In addition, as part of credit, company $\mathrm{X}$ will burden the cost of interest that is calculated in this example as 164,138 TL. Therefore, the total cost of financing for company X will be 479,138 TL which are reflected as separate cost items in the above table.

In our case, we estimate that the residual value of Toyota Corolla Hybrid will be 253,445 TL, based on 3 years of use and with a total mileage of 90,000. This has a plus sign in the analysis as it is a revenue item, and it will reduce the total cost for company $\mathrm{X}$.

Costs that the Table 1 presents are not pretty much different than the supplier would need to take into consideration in estimating the monthly lease cost of Toyota Corolla which will be offered to company $\mathrm{X}$ in case of leasing. The supplier calculates a monthly lease cost amounting 6,432 TL. This would be the cost for company X throughout the agreed lease term and would be paid on monthly basis if it were to choose leasing option. Lastly, to note that it expected that the supplier has also better terms and cost advantage in services due to its nature of business that stems from the supplier's service agreements with dealers which is usually on volume basis. For this reason, maintenance \& repairs, and tyres account in estimation for $20 \%$ mark-up for company $\mathrm{X}$.

Based on all of these estimations and calculations, it can be seen that company $\mathrm{X}$ would in this case be better off if it takes on a leasing contract from the supplier. In leasing option, it will be 
ending up with paying 173,664 TL in total and compared to purchasing, it saves the company 34,251 TL. The outcome of this analysis can produce different results for each vehicle considering internal company effects and external conditions. Therefore, it is only intended to propose a general understanding of the situation that companies might be addressing to in their decision-making process.

\section{From TCO to TCM}

The economics within this traditional TCO setup can be, in general, summed up under two types of costs - explicit and implicit costs. Explicit costs can be further dived into two categories which covers financial and operating. Financial costs are those related to financing and deprecation of a vehicle. Operating costs can cover maintenance and repairs, tyres, insurance, road and similar taxes and fuel. Implicit costs, on the other hand, are the costs that cannot be directly included in calculation or at least that is hard to estimate prior to putting the vehicle on road. End-of-contract charges, opportunity costs, downtime costs, toll and parking costs can be given as examples of the implicit costs.

How companies may approach to measure the TCO can vary between them as to whether the implicit cost of the TCO such as the opportunity costs, parking and toll expenses need to be a direct element of cost calculations. This gives rise to an implication that even within the traditional TCO concept, there could be different approaches adopted by companies. Therefore, even when the same car is selected by two different companies, ceteris paribus, the actual TCO calculated from the same car could yield a different result. This is because the scope and the baseline of the calculation would not be identical between these two companies, hence, an error margin is needed to compare the actual TCOs of the same car (GlobalFleet, 2019). This leads us the question that how should a company properly measure the TCO of its vehicles?

Although it can be concluded that companies can apply different approaches in deciding upon what costs elements need to be part of their TCOs, a general interpretation by most of the leasing companies that a vehicle's TCO has at least to include the following:

- Depreciation

- Interest cost

- Repair, maintenance, tyres, and roadside assistance

- Insurance

- (Road) tax \& fees

- Management fee ${ }^{6}$

\footnotetext{
${ }^{6}$ It is paid out to the leasing company as for the purpose of receiving operational assistance and commercial support, in most cases from a dedicated account manager.
}

Copyright (C) 2020, Journal of Advanced Research in Economics and Administrative Sciences (JAREAS), Under a 


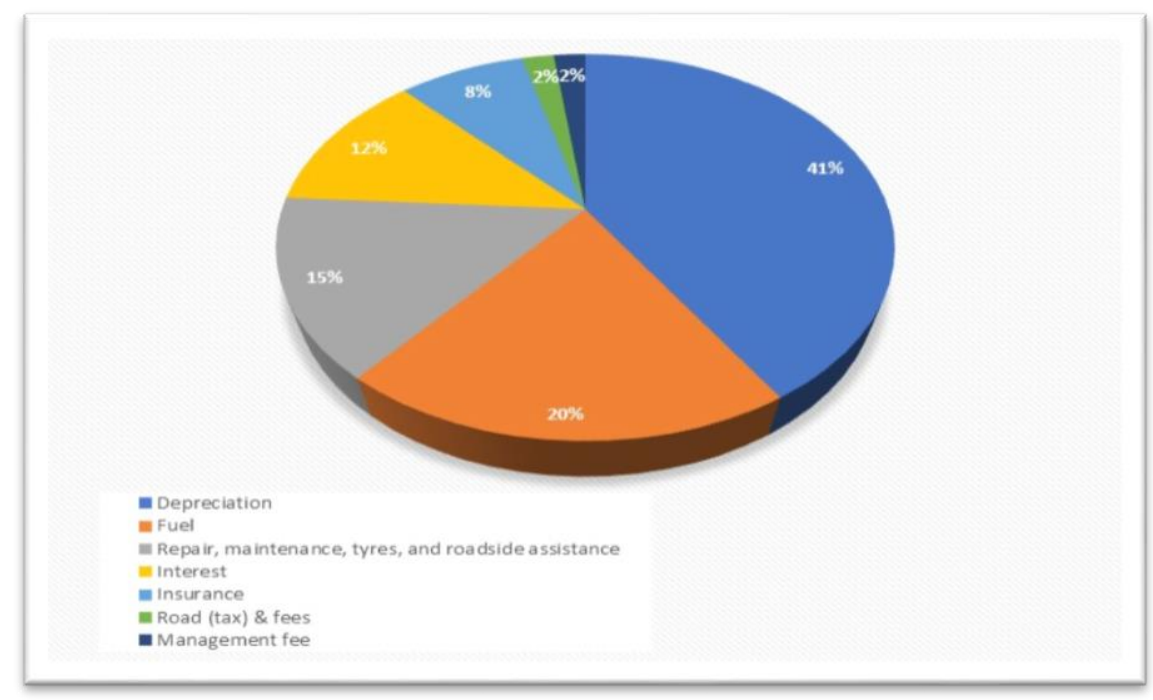

Figure 1: Average TCO for company car in Europe Source: Deloitte

Figure 1 depicts a typical TCO breakdown for a European fleet vehicle. Depreciation constitutes around $40 \%$ of the TCO which makes it the largest part of costs of a vehicle over its use period. Fuel costs takes the second largest portion with about $20 \%$ whereas interest costs comprise $12 \%$ of the TCO. RMTR costs has a weight of $15 \%$ of the TCO. This means $40 \%$ of the TCO can be accounted to the actual vehicle, while $60 \%$ of the costs emerge throughout the use of the vehicle. In Turkey, in contrast, interest and fuel comprise, on average, around $68 \%{ }^{7}$ of the TCO split because of high funding costs and fuel prices. In addition, as opposed to many countries in Europe, Turkey has a market in which companies more upfront price oriented and the TCO consideration in vehicle selection is around 20\% (GlobalFleet, 2020).

A key point for a company which has an international presence in several countries might be to consider differences in the related TCOs as country specifics play an important role in the cost set-up. For example, in Sweden maintenance, repair and insurance costs corresponds to the most expensive part of the total costs (per month), whereas in Turkey, costs for maintenance and repair are lowest ${ }^{8}$ in Europe. As another example, in the Netherlands driving a diesel car is most expensive while fuel costs in Hungary are the cheapest across Europe (GlobalFleet, 2017). Therefore, for companies wishing to optimise costs an important area to pay attention is what type of vehicle is driven in the fleet.

Taking this a step further, it can be put forwarded that the most important component of fleet decision is vehicle selection. It is because it has a direct impact on a company's TCO calculation. When deciding upon the type of a vehicle, companies need to make a solid assessment considering their internal economic goals, budgets and sustainability strategies as every vehicle has its economic, operational, and environmental strengths and weaknesses (Bai, Fahimnia, \& Sarkis, 2017). Among all, vehicle characteristics are the most popular criteria in traditional vehicle selection process and can cover the monthly lease cost in case of leasing or the price of a vehicle in case of purchasing, vehicle's residual value, cost of operations such as maintenance, tyres and insurance, dealers and service networks, technology, accessories and

\footnotetext{
${ }^{7}$ Source: Borlease Fleet Services

${ }^{8}$ Labour cost could explain the difference between both extremes.
} 
equipment level, fuel consumption, pollution emissions, guarantee coverages and NCAP results. The list can be further expanded.

In addition to the vehicle selection, there are two important exogenous variables that affect the TCO of companies. First one is the yearly milage that a vehicle will make per annum and the second one is the expected use time of the vehicle. The former is quite crucial to know before calculating the TCO of a vehicle. Vehicles run on mileages and mileages of a vehicle drives the main costs. Without knowing it properly, an accurate cost estimation cannot be made possible and then, a company can miss its yearly vehicle budgets that accounts for one of the largest expense items in their financial records. Therefore, a company might fail with its overall KPIs.

Having a vehicle selected and an estimated yearly mileage in mind, the expected use time of a vehicle will help calculate the rest. Given a high yearly mileage - say 50,000 per annum - the longer the use period a vehicle will be driven for, the higher the costs will be accumulated. Moreover, the residual value will diminish implying that greater part of depreciation costs will be included in the TCO calculation or anyhow the lost in value will be actualised when the vehicle is disposed ${ }^{9}$. Thus, vehicle selection again steps in as to mitigate the loss in value at the time of disposing. Companies can minimize this loss by selecting vehicles with relatively high potential residual values in the market.

For a company, forecasting the true residual value of the vehicle at the end of use is the crucial ability for estimating the TCO. It cannot only help determine the true costs but also can lead to profit generation when the vehicle is disposed. Gains from the vehicle remarketing is a great contributor for profits when a vehicle is sold for a higher price than the initial forecasted residual value. Hence, a vehicle residual value can be a significant contributor to the fleet's economic sustainability in addition to financing capabilities and purchasing power of a company.

The Total Cost of Mobility (TCM), on the other hand, is a much broader term that also encompasses the TCO. The TCM context of cost optimization is in very early stages in the business world and is not very easy to model a pure TCM concept. At first sight it can be easily stated that the TCO provides a cost calculation per vehicle and per driver while considering the pure economic considerations. the TCM concept covers the mobility of things that is the conveyance of people, their belongings, or the goods and produces of companies that is performed with the most economically optimum and efficient way and in a socially responsive and environmentally friendly way. So, its calculation reflects all costs ranging from the company vehicle itself , so to speak, the TCO, and other related costs of mobility options that a company uses for its vehicle fleet operations such as flights, car-pooling, subways, car sharing, taxis, rental cars, bikes, scooters and of course all types of electric mobility ${ }^{10}$. Even the TCM should consider cash allowances that a company pays out to its employees against not utilised vehicle

\footnotetext{
9 That is also certainly true that there are some other internal and external factors that can reduce (or increase) a vehicle's residual value. Improper use, high accident ratios, interior damages, economic crises, vehicle abundances and supply shocks are just few to name. For example, at the time this paper is written, another aftermath of the COVID-10 pandemic has been witnessed on the supply of semiconductor chips which is creating shortages that in turn has forced automotive companies to pause or delay their vehicle productions to a later time 2021 or could stretch 2022. This will increase the demand for used vehicles and, hence, their prices (i.e., the residual values) will increase. According to Manheim Market Report used vehicle prices has rocked up for the first two weeks of April which indicates a $52 \%$ increase in the re-sale values on a year-over-year basis*.

*source: https://www.bloomberght.com/sirketler-cip-krizi-nedeniyle-ikinci-el-araca-yoneldi-2279646

10 The TCM model greatly aims to promote the use of e-vehicles, e-busses, e-bikes, e-scooters, and anything that can be included as a mode of transportation and can be defined as a fleet vehicle.
}

Copyright (C) 2020, Journal of Advanced Research in Economics and Administrative Sciences (JAREAS), Under a 
and the time spent by walking of an eligible employee to get to the office and back home. Hence, the TCM in fleet management withing a company requires a holistic multi-modal point of view.

From an economic point of view, in the TCO context companies try to optimize their costs, especially for vehicle purchasing, financing and fuel. In the TCM model, companies need to optimize the TCO while reducing their fleet related total cost of travel expenses. Taking the TCM as a dependent variable of all available fleet mobility solutions, the following model can be reached out:

Model 1: Total Cost of Mobility (TCM) in Fleet Management

$$
\begin{aligned}
& \mathrm{TCM}_{\mathrm{FM}}=\mathrm{CA}_{\mathrm{FM}}+\mathrm{TCO}_{\mathrm{FM}}+\text { E-Mobility } \\
& \text { Remarketing }+ \text { Volume Rebates and Commissions }+ \text { Bonuses })_{\mathrm{FM}}+\mathrm{U}_{\mathrm{FM}}
\end{aligned}
$$

where:

- $\mathrm{TCM}_{\mathrm{FM}}$, is the total cost of mobility in fleet management,

- $\mathrm{CA}_{\mathrm{FM}}{ }^{11}$, cash allowances that a company pays out as a benefit to its eligible employees who do not actually need or want to drive a company car,

- $\mathrm{TCO}_{\mathrm{FM}}$, is the total cost of ownership of operating fleet vehicles,

- E-Mobilityfм ${ }^{12}$, denotes the cost of electric mobility options such as electric vehicles that a company can take on and the cost of charging solutions and investments needed to keep vehicles operating,

- T-Mobilityfм, is the cost of conventional travel options such as car sharing, taxis, daily rental, ferry, and railroads,

- Tech $_{\mathrm{FM}}$, is the cost of technology necessary to integrate all options into a single userfriendly application to keep track of all fleet related expenses, time, and efforts ,

- (Gains from Remarketing + Volume Rebates and Commissions + Bonuses) FM $^{13}$, are the proceeds that a company can financially claim over the utilization of its vehicle fleet.

- U UM, other costs that cannot be pre-estimated but can possibly arise as a direct result of operating fleet vehicles, such as parking, and toll fees, reimbursements to drivers and other similar items expensed on accrued basis which are not included in the model.

Companies can see the components of the TCM as substitutes for or complementary to each other and decide to take off or add more of it into this equation. But the main conception behind this formula is that it presents a flexibility of performing their fleet management activities.

The TCM itself does not propose whether the leasing, outright purchasing or short-term car rental is the best of all among options for companies to adopt and implement but rather addresses what needs to be done should be done in conjunction with the long-term requirements of the company strategies in fleet management and with the necessities have brought by the external

\footnotetext{
11 As a company strategy or an employee's own will, utilization of a fleet vehicle can be replaced with a predetermined amount of cash. In case of an employee's own will, she/he might be using her/his own car or just does not want to take a company vehicle and spare the cash for other consumption goods (or might save it).

12 Electric vehicles are a big part of electric mobility. They have inherently their own TCO approach that is needed to be addressed separately than conventional vehicles as the costs of charging infrastructure and electricity should also be included.

${ }^{13}$ Volume rebates and comissions are especially applicable when companies order high quantities of vehicles with a strong purchasing power while bonuses are the revenues recevied from dealers and services on prefering them as suppliers.
}

Copyright (C) 2020, Journal of Advanced Research in Economics and Administrative Sciences (JAREAS), Under a 
environment. The TCM consideration can help companies diversify their mobility strategies with a granting greater flexibility. Greater flexibility in mobility is of crucial especially in uncertain times like the Covid-19. For companies having an agenda on a well-considered options of unbundled mobility applications in their fleet management can save them money and help them quickly respond to market challenges.

\section{Environmental Sustainability in Fleet Management}

With the enforcement of the Paris Agreement, the European Union has the long-term commitment to decrease its greenhouse gas emissions by $80-95$ percent by 2050 compared to the levels of 1990s. between 1990-2015, emission levels were reduced in almost all business sectors. The only exception is the transport sector that stands a big barrier for EU's commitment to achieve its goal as the sector has standalone been responsible for an increase of $23 \%$ percent of the greenhouse gas emissions. Decarbonising road emissions within the transport sector is of crucial importance since road transport produces around $73 \%$ of all emissions. Within that, cars constitute the largest share with almost $45 \%$ of all road transport emissions. To reach out the "net zero emissions' target by 2050, as implied by the Paris Agreement, transport sector must be completely decarbonised (Tagliapietra \& Zachmann, 2018). Net zero emissions refers to balancing a measured amount of carbon emitted with an equivalent amount offset or cut off or buying sufficient carbon credits to make up the difference (LeasePlan, 2017).

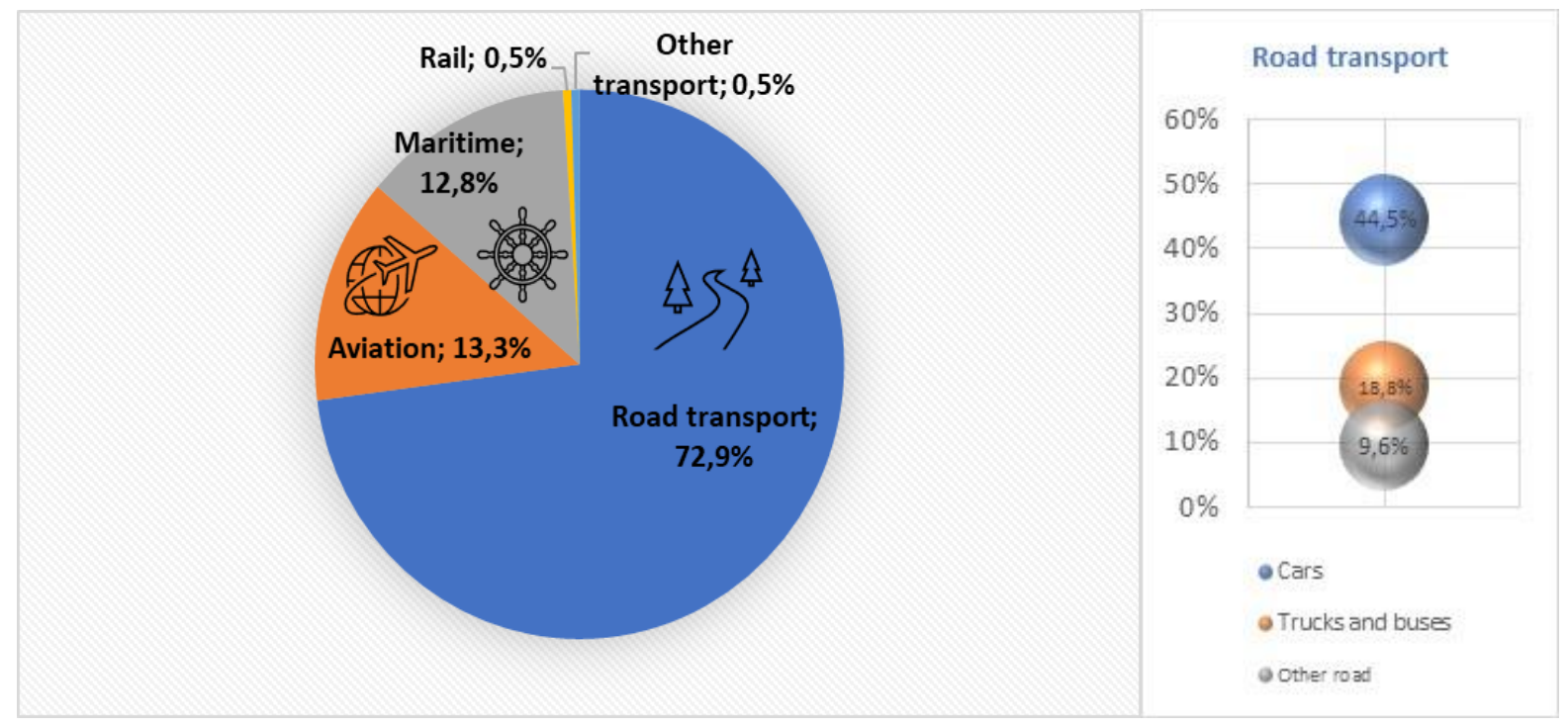

Figure 2: EU transport greenhouse gas emissions by mode, 2015

Source:https://bruegel.org/reader/EU_failure_to_clean_up_transport_sector\#transport-a-major-obstacle-toeuropean-decarbonisation

In this regard, companies face many external pressures, especially from governments and local authorities, to reduce their vehicle fleet emissions. In the context of fleet management, becoming green is not always at a high priority for all companies. However, it is getting important each and every day for companies to reduce their vehicle emissions as their vehicle fleets certainly contribute to the carbon footprints of business operations. It is certain that technological developments can facilitate companies an easy shift from conventional fossil-fuelled vehicles to green vehicles However, dealing with this issue entails a through consideration and it is not simply a matter of leasing or replacing current fleet with new electric vehicles. Companies should plan for a step-by-step transformation that would require a company level buy-in and needs to be embedded in the long-term company strategy.

Copyright (C) 2020, Journal of Advanced Research in Economics and Administrative Sciences (JAREAS), Under a 
The environmentally focused fleet management can start with adoption of an environmentalcentric fleet policy. This will be a baseline for setting environmental goals, targets and KPIs that are regularly reviewed and implemented. An effective one needs to include a commitment by the company's top management, requires perpetual improvements that should be in line with changes in the actual legal and tax perspectives and the market requirements. It should be written, maintained for the long-term and communicated to all employees and preferably be publicly reachable that will gain credit to the company (Wong \& Fryxell, 2004).

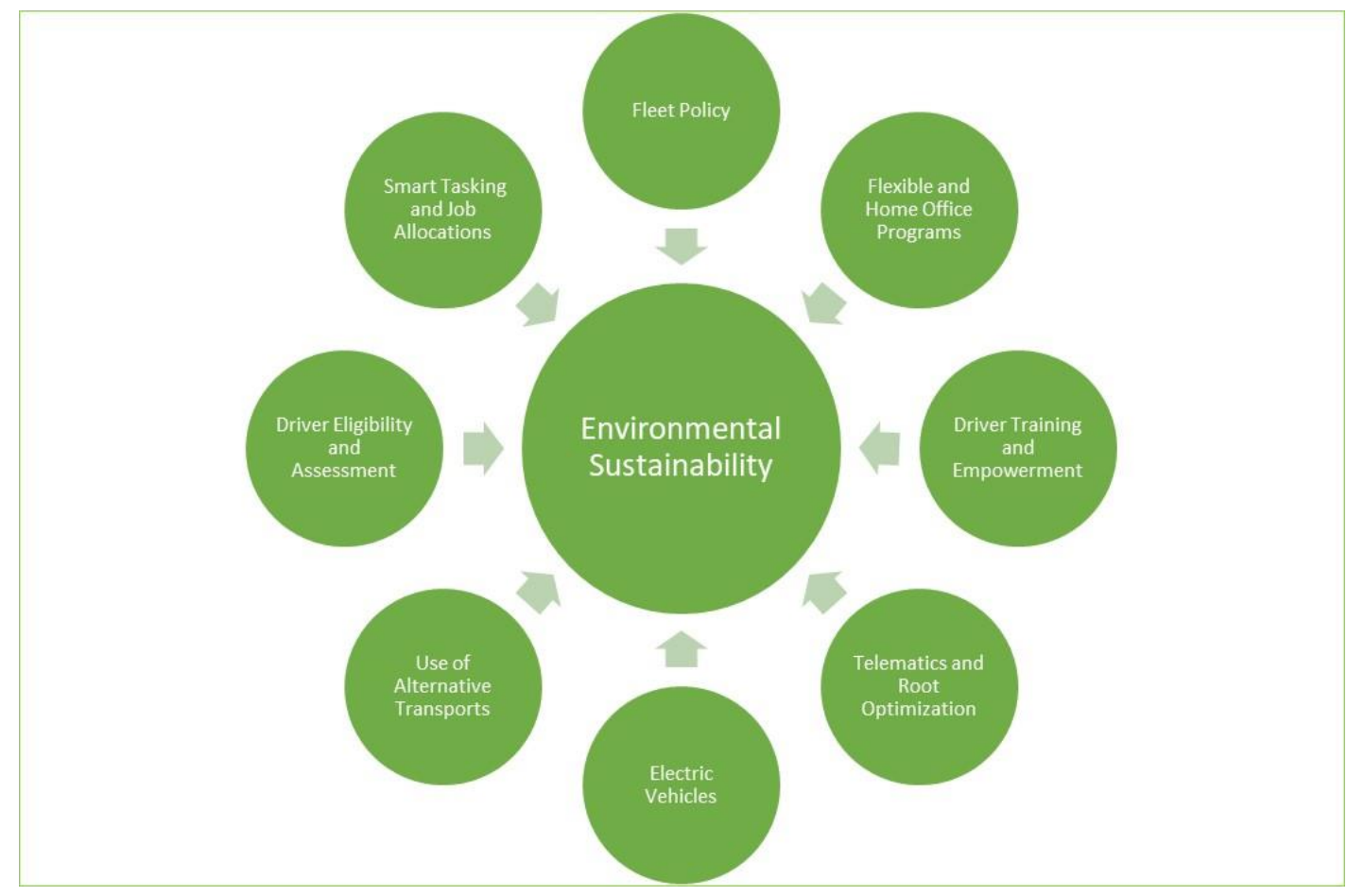

Figure 3: Environmental sustainability in fleet management

This policy should inevitably have a green criterion and needs to be very flexible enough to benefit from constantly improving technologies. Making a switch to a greener fleet indeed is one of the easiest ways for companies to reduce their fleet's emission levels. On the other hand, budgets cannot always afford the higher upfront costs of EVs even though the government supports and lower lifetime costs (Gorrie, 2013). Even though manufacturers have expanded and diversified their EV lines and offerings, companies have been reluctant to invest in EVs since their investment decisions are affected by the uncertainty of the cost-benefit ratio. (Al-Alawi, Baha, \& Bradley, 2013) showed that $80 \%$ of respondents stated that the purchasing price is the most important determinant in the decision of buying an EV yet lower running costs in comparison to the conventional fuelled vehicles. In this survey, fleet managers expressed that they were be convinced to buy an EV if its payback period considering savings generated from its running-costs was limited only limited to 4.7 years. Nevertheless, according to the same survey $65 \%$ of 500 fleet managers agreed that the uptake of EVs would definitely help their companies in achieving their sustainability goals (Daina, 2020). With technological developments, EVs are expected to be cheaper in purchasing price than conventional fuelled ones as soon as 2025. Battery prices that comprise about half of the cost of EVs will fall about 77\% until 2030 and with more stringent regulations, conventional vehicles will get more and more expensive (IndustryWeek, 2107). Companies should definitely promote and include EVs in their vehicle fleets as this constitutes the big part of their transformation strategy for achieving environmental sustainability objectives. 
Aside from an ongoing process of EV transformation, companies can quickly implement environmentally sustainable fleet management solutions that can have an impact on delivering immediate green results. Companies can re-address who is eligible for a company car and who really needs to drive a vehicle for business purposes. If there are some employees who do not make regular use of company vehicles can be offered flexible mobility options including public transport, taxis, sharing cars and even cycling if possible. Especially in crowded urban areas, companies are shifting from proving their employees with a company vehicle to cash allowances so that employees can make their own travels by exploring public transport opportunities. With the impact of the Covid-19, more and more companies are shifting from office to home working programs that is immediately have help reduced the $\mathrm{CO}_{2}$ emission of their carbon footprints. This would imply less company vehicles will be provided to each eligible employee but would promote alternative use of mobility that is environmentally friendly.

Another quick win can be achieved through smart tasking and job allocations that will not only help reduce the utilization of vehicles but could also reduce total mileage driven and carbon footprint of companies. In addition to that, companies, assisted by telematics systems or any similar technological software and hardware systems, can monitor vehicles - including where they go and how fast they can get there - and optimize vehicle roots and discourage improper driving behaviours. Root optimization can mean savings in travel times and thus, reduction in $\mathrm{CO}_{2}$ emissions.

Driver behaviours can be another area investigation for companies as their actions regarding driving style, controlling vehicle load, and checking tyre pressures are just a few things that can easily have an impact on emission levels of their vehicles. Fast accelerations or breaking, leaving the engine running while a vehicle stationary and excessive speeding are basic driver features that affect negatively on fuel consumption and $\mathrm{CO}_{2}$ emissions. Driver trainings, empowering them to affect the change, making them responsible for their actions and rewarding good driving behaviour in this context can offer immediate improvements to reduce fuel consumption and hence $\mathrm{CO}_{2}$ emissions. An effective environmental fleet policy should limit or thresholds that are aligned with manufacturers' targets. A company can choose vehicles for each segment up to a certain maximum $\mathrm{CO}_{2}$ limit per vehicle. Many companies, especially international ones, already set limits for their vehicles, incorporate them into their fleet policies and try to implement in overseas operations.

Environmental sustainability objectives can be implemented in many different ways: a gradual reduction of emissions, adopting EVs, vehicle optimisation, smart rooting, driver trainings and perhaps some more. Whichever a company prefers to take on, it needs to be scalable. A correct analysis of what is needed to support the environmental policy is of great importance and company-wide acceptance of the policy by all stakeholders is crucial to its success.

\section{Social Sustainability in Fleet Management}

The social pillar of sustainability is more connected to the well-being of people and society which seeks to find a balance between the needs of persons and communities and what the nature can provide them to sustain the ecosystem (Sungchul \& Ng, 2011). Similarly, from a business point of view, social sustainability is to understand and be aware of the effects of actions taken by companies on both individuals and society. This can include variety of concerns such as human rights, health, safety, diversity, treating employees and living conditions (ADEC Innovations, 2021). Over the years, companies have been implementing the social dimension of

Copyright (C) 2020, Journal of Advanced Research in Economics and Administrative Sciences (JAREAS), Under a 
sustainability in their Corporate Social Responsibility (CSR) ${ }^{14}$ framework (Sungchul \& $\mathrm{Ng}$, 2011) and companies see the CSR concept as a commitment to eradicate or minimize the detrimental impact of activities whilst aiming to create the value that a society and its inhabitants can benefit in the long run (Lois, Deborah, \& Katherine, 2001).

Fleet management is definitely a big part of CSR framework and companies are also responsible for their fleet operations as they can have a huge impact on the health and safety of the vehicle users. Besides, fleets are also directly affecting all road users. Therefore, companies need to take some issues into consideration while running their fleet vehicles (Malacarne, Eleonora, 2018). Figure 4 portrays the four important factors that are intertwined with each other and can be attributed to the social sustainability in fleet management.

Health and Road Safety: It is important for companies to focus on the well-being of their drivers when they use company vehicles. They need to have a well-developed fleet policy, or at least a duty of care, both towards employees and society which would mean in the case of driving to other road users and pedestrians. Drivers need to be encouraged to drive in the safest possible way and any possible risk related to driving should be minimised (Malacarne, Eleonora, 2015).

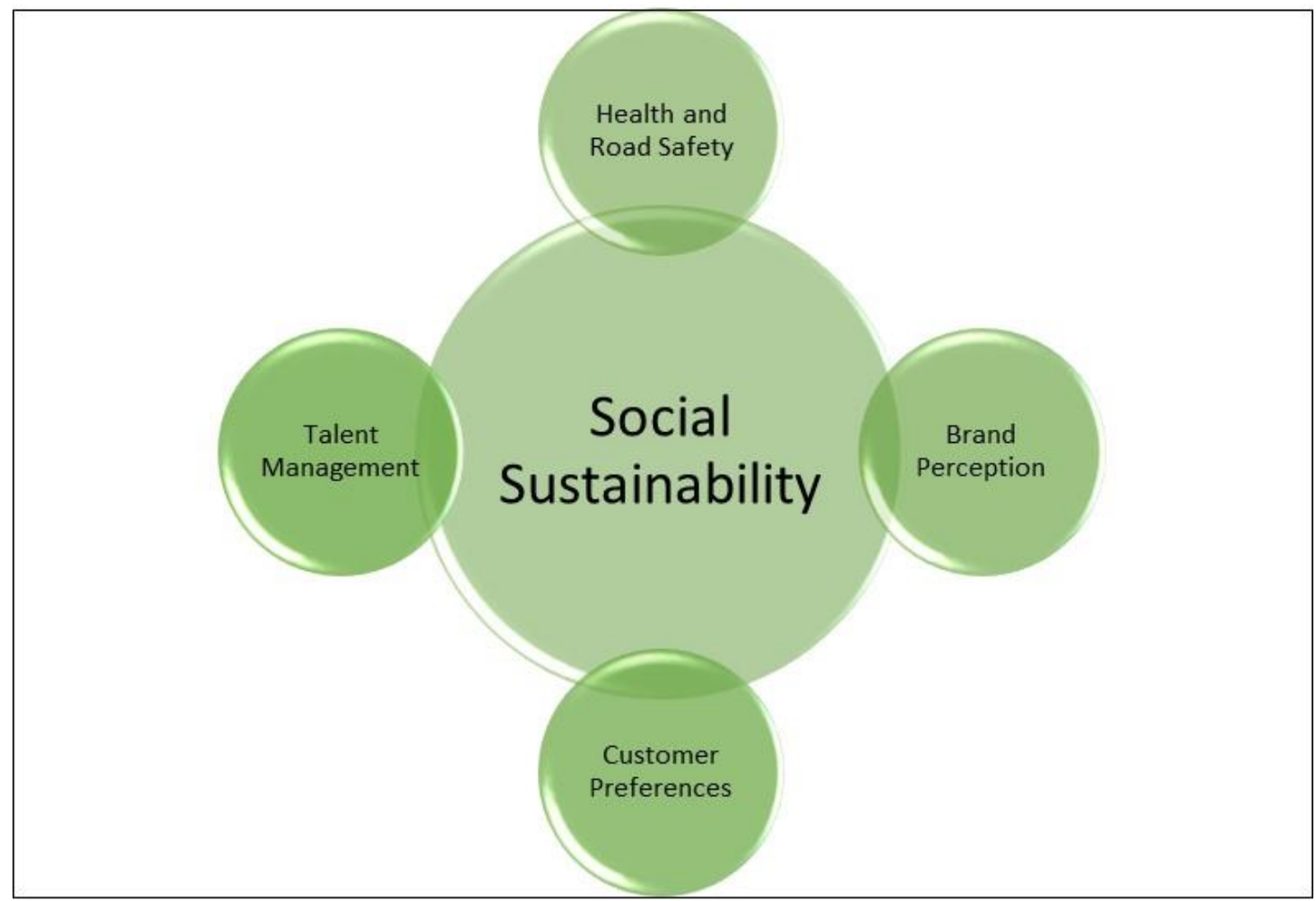

Figure 4: Four factors in the social pillar of fleet management

Because companies are running fleet vehicles, they also create externalities to society. Disturbance caused by sound, for example, is an intangible cost to the public that is known as noise pollution that can usually stem from an engine and rolling parts of a vehicle. Any level above 70 decibels could be very harmful and would be a reason for high blood pressures, cardiac infractions, create vibrations to buildings and homes. Traffic accidents, for example, give rise to

\footnotetext{
${ }^{14}$ Environmental concerns generally comprise a big part of CSR activities for companies. Environmental thought in fleet management is considered to be one of the separate pillars of sustainability and it is not presented under the CSR framework.
}

Copyright (C) 2020, Journal of Advanced Research in Economics and Administrative Sciences (JAREAS), Under a 
deaths, casualties, they have an impact on people and their beloved ones in financial and emotional ways and creates other types of material losses. Congestion as another type of externality is a big contributor to traffic jams (Singh, Gurtu, \& Singh, 2020). It reduces utility of a vehicle as it hinders completely or paces down mobility and gives rise to difficulties in driving the car (Nunes \& Bennet, 2010). In addition to that, it causes people to get to their offices late, loss in productivities and affect the performances of the related ecology (Singh, Gurtu, \& Singh, 2020) . Traffic congestion also Therefore, the fleet policy should address the potential health and road risks with a purpose how these risks can be minimised. Measures and items that can be promoted as part of company KPI's might include performing regular vehicle condition and maintenance, monitoring accident rates and their causes, analysing driver behaviours through telematics solutions, organizing trainings for safe driving, keeping track of driving history of vehicle users, and incorporating speed limits on vehicle use especially in longer distance driving, and encouraging drivers to take coffee breaks when they feel exhausted are just some of the few ones but they are of crucial. These can be highly effective in improving fleet and global safety with the involvement of company's human resources department.

Brand Perception: Vehicle fleets are no exceptions to the fact that they are used by companies as a creative tool for marketing and promoting of corporate image. As drivers are on the road to maintain the continuity for their sales, delivery, and other business operations, they can be also the focus to attract attention to corporate business. Driving vehicles in a careful and socially expected driving manner, managing incidents at low levels, keeping vehicles in good condition, well-maintained and clean at all times, not using mobile phones while driving and not smoking in vehicles can be indeed small steps that a company might take but they greatly contribute to a company's image and can be a good signal of corporate desire to do the right thing. Companies usually prefer branding (name, logo, or website information), especially when they have field services, on the side of their fleet vehicles. As fleet vehicles are used, other drivers, road users and society are becoming more and more knowledgeable about company name, they will be prone to visit website of company, and tend to search for company name. Therefore, companies can build up their brand through such PR media while attracting more potential customers.

Customer Preferences: The importance that the society has a positive view of and acknowledgment about a company's fleet vehicles driving around is the distinction between winning and losing customer (Jenny Shiner , 2017). People are increasingly becoming "the socially conscious consumers" whose decision to buy, use and dispose of a product in an attempt to eliminate any detrimental effects to environment and maximize the impact on society in the long-run. Consequently, those consumers want to work with and buy products and services from companies that does not give any damage to society (Lois, Deborah, \& Katherine, 2001). Moreover, according to (Sungchul \& Ng, 2011), customers give responses more negatively to companies which have weak and insufficient sustainability initiatives than those with high sustainability. Additionally, if companies share the social causes of their actions with the public, this can help companies to be perceived and evaluated more favourably in the eyes of customers (Sungchul \& Ng, 2011). Hence, companies need to acknowledge and consider the implicit effects of using fleet vehicles which can be a good reason and the main argument that a customer preferring the company or the competition.

Talent Management: Lastly, there is another reason why a company's vehicle fleet should be treated as part of their CSR as it certainly appeals to its employees. Aside from their central role being used for sales and business operations, they have also been seen as a way to retain or entice the best employees and talents in the market. So, having a company car is among one of the biggest benefits employees look for in a job. On the flip side of the coin, the great number of

Copyright (C) 2020, Journal of Advanced Research in Economics and Administrative Sciences (JAREAS), Under a 
people have started to work for a company with a social performance that is line with their own values (Sarah Tooze, 2013). In the case of fleets and drivers, when selecting a company car, drivers give importance to the features such as safety, fuel efficiency, convenience, being environmentally friendly, greener, and quieter. As companies include more vehicles with these features in their fleet composition, they will be more socially admired and acknowledged. And as they are getting more and more known by society, there will be more talents want to work for these companies. This continuum would, in turn, produce a "virtuous circle" in which company image will further improve.

As many companies understand and value the need for being a responsible employer of a market and wish to promote itself in a society (Marchet, Melacini, \& Perotti, 2014), the importance of having appropriate fleet management applications and practices also growing in their CSR context. As explained, company vehicles have a direct impact on road safety, health, employee well-being and on some others. Therefore, it is key for companies that a successful CSR policy gains buy-in at high level within a company and employee engagement, with the inclusion of human resources department, at all levels is crucial to its success (Sarah Tooze, 2013).

\section{Conclusion and Suggestion}

Sustainability has attracted scholars over the years and has become an area of interest in various fields, including automotive, logistics and supply chain management. In these studies, the Triple Bottom Line (TBL) approach is widely used from the perspectives of economics, environmental and social. In this paper, Triple Bottom Line (TBL) approach is used to address these three pillars of sustainability issue in company fleet management. To the best of my knowledge, there is no pervious explanatory study performed to investigate the role of economic, environmental, and social pillars in fleet management therefore, the major contribution of the present paper is twofold. First, this work is one of the earliest studies in this subject and second, it aims to provide companies with a policy advice in three dimensions of sustainability while addressing their relevance and applicability to company fleet management.

The economic dimension of sustainability discusses the TCO and the TCM concepts and presents that the TCM is a broader model that covers the TCO which is the conventional way of assessing economic cost of fleet vehicles. In addition, the TCM model includes the mobility of things phenomenon that is the conveyance of people, their belongings, or the goods and produces of companies that is performed with the most economically optimum and efficient way and in a socially responsive and environmentally friendly way. Moreover, it is a holistic multimodal mobility concept in fleet management. Also, the TCM put forwards that companies can use variety forms of mobility choices that would help them take on greater flexibility and cost advantages. Needless to mention that the TCM approach would also strengthen companies' hands to adapt to the rapidly changing market environments.

As regards the environmental sustainability, companies have started to pay greater attention to environmental issues particularly due to the pressures arising from the external factors such as governments, regulations, suppliers, and customers. Company vehicle fleets, as part of road transport, are one of the biggest contributors to the greenhouse emissions. Reducing or preferably preventing the adverse environmental effects of use of fleet vehicles should be one of the priority areas for companies to achieve. Companies should have an environmental oriented

Copyright (C) 2020, Journal of Advanced Research in Economics and Administrative Sciences (JAREAS), Under a 
fleet policy that aligns with company strategic objectives and needs to guarantee the involvement of the top management. A companywide commitment to this policy will be a very important step to succeed the environmental goals. Quick wins can appear in various forms such as the assessment of eligibility of employees for a company vehicle; driver empowerment and trainings; use of alternative transport; smart routing, optimization and use of technology; and further applications and variations of home-office working policies. The uptake of electric vehicles (EVs) will be one of the most important steps that a company would make forward. A gradual transformation to the EVs is of crucial and entails a prudent planning.

The social pillar of sustainability has perhaps taken the least priority for companies, and they seem to be less concerned with it. The social pillar should place the society and well-being of people in the centre of an effective and well-designed CSR policy. Fleet management, in this regard, is closely attached to the CSR framework as vehicles are attributed not only to the health and safety of drivers but also to all road users and their surroundings. There are some considerations companies can pay attention while evaluating the social dimension of fleet management. These considerations are not limited to but connected to health and road safety, brand perception, customer preferences, and talent management.

While this paper has provided a policy advice to companies in fleet management and aimed to be an early attempt in this area, an empirical study is recommended in the next step. The subsequent study can investigate, and then map the sustainability practices of the randomly selected bundle of international and local companies currently present in Turkey, while defining a basis conferred with the industry experts for the purpose of comparison of the results obtained from those companies. This would, therefore, help understand the applicability of the three pillars of sustainability in fleet management as a concrete concept.

\section{Acknowledgements}

We appreciate anonymous referees for their suggestions.

\section{Conflict of Interests}

The authors declare no conflict of interest.

\section{Funding}

For this research work, the authors did not receive funds from any organization.

\section{References}

ADEC Innovations. (2021). What Is Social Sustainability? ADEC Innovations: https://www.esg.adec-innovations.com/about-us/faqs/what-is-social-sustainability/

Al-Alawi, Baha, M., \& Bradley, T. H. (2013). Total cost of ownership, payback, and consumer preference modeling of plug-in hybrid EVs. Applied Energy, 103, 488-506. doi:https://doi.org/10.1016/j.apenergy.2012.10.009

Ateş, M. A., Bloemhof, J., van Raaij, E. M., \& Wynstra, F. (2011, July 05). Proactive environmental strategy in a supply chain context: the mediating role of investments. International Journal of Production Research, 50, 1079-1095. doi:10.1080/00207543.2011.555426 
Aybalya, R., Laura, G.-K., Manierea, I. C., Madacovaa, D., \& van Holt, J. (2017). Sustainability practices in the luxury industry: How can one be sustainable in an over-consumptive environment? Information Technology and Quantitative Management, 541-547. doi:10.1016/j.procs.2017.11.404

Azevedo, S., \& Barros, M. (2017, February). The Application of the Triple Bottom Line Approach to Sustainability Assessment: the Case Study of the UK Automotive Supply Chain. Journal of Industrial Engineering and Management, 10(2), 286-322 . doi:10.3926/jiem.1996

Bai, C., Fahimnia, B., \& Sarkis, J. (2017). Sustainable transport fleet appraisal using a hybrid multi-objective decision making approach. Annals of Operations Reseacrh, 250. doi:10.1007/s10479-015-2009-Z

Beatriz, B. O., Maria, A. C., \& José, F. O. (2016). Fleet and revenue management in car rental companies: A literature review and an integrated conceptual framework. Omega, 71, 1126. doi:10.1016/j.omega.2016.08.011

Benjamin Uyttebroeck. (2020, November 18). Pim de Weerd is European Smart Mobility Manager of the Year. Retrieved from fleeteurope.com: https://www.fleeteurope.com/en/maas/smart-mobility/europe/features/pim-de-weerdeuropean-smart-mobility-manageryear?a=BUY03\&t $\% 5 B 0 \% 5 \mathrm{D}=$ Fleet $\% 20$ Europe $\% 20$ Summit\&t $\% 5 \mathrm{~B} 1 \% 5 \mathrm{D}=$ Fleet $\% 20$ Eur ope $\% 20$ Awards\&t $\% 5 \mathrm{~B} 2 \% 5 \mathrm{D}=$ Philips\&t $\% 5 \mathrm{~B} 3 \% 5 \mathrm{D}=$ Geotab\&curl $=1$

Chen, Y., Lai, S., \& Wen, C. (2006, July). The Influence of Green Innovation Performance on Corporate Advantage in Taiwan. Journal of Business Ethics, 67(4), 331-339. doi:10.1007/s10551-006-9025-5

Chiara, B. D., \& Pellicelli, M. (2016). Sustainable road transport from the energy and modern society points of view: Perspectives for the automotive industry and production. Journal of Cleaner Production, 133, 1283-1301. doi:10.1016/j.jclepro.2016.06.015

Chiara, D. B., \& Pellicelli, M. (2016). Sustainable road transport from the energy and modern society points of view: Perspectives for the automotive industry and production. Journal of Cleaner Production, 133, 1283-1301. doi:10.1016/j.jclepro.2016.06.015

Chiou, T.-Y., Chan, H. K., Sai, F. L., \& Chung, H. (2011, November). The influence of greening the suppliers and green innovation on environmental performance and competitive advantage in Taiwan. Transportation Research Part E: Logistics and Transportation Review, 47(6), 822-836. doi:10.1016/j.tre.2011.05.016

Chithambaranathan, P., Subramanian, N., Gunasekaran, A., \& Palaniappan, P. (2015). Service supply chain environmental performance evaluation using grey based hybrid MCDM approach. International Journal of Production Economics, 166, 163-176. doi:10.1016/j.ijpe.2015.01.002

Daina, N. (2020, July). Private e-mobility vs e-fleet: Fixing the public charging infrastructure paradox. Retrieved from oxfordenergy.org: https://www.oxfordenergy.org/wpcms/wpcontent/uploads/2020/07/OEF122.pdf

Deloitte. $(2017,7)$. Fleet management in Europe: Growing importance in a world of changing mobility. Retrieved from Deloitte: https://www2.deloitte.com/content/dam/Deloitte/us/Documents/consumer-business/usfleet-management-europe.pdf

Copyright (C) 2020, Journal of Advanced Research in Economics and Administrative Sciences (JAREAS), Under a 
Diaz-Garcia, C., Gonzales-Moreno, A., \& Saez-Martinez, F. J. (2015, April). Eco-innovation: insights from a literature review. Innovation, 6-23. doi:10.1080/14479338.2015.1011060

Elmquist, M., \& Segrestin, B. (2009). Sustainable development through innovative design: lessons from the KCP method experimented with an automotive firm. Internal Journal of Automotive Technology and Management, 9(2), 229-244. doi:10.1504/IJATM.2009.026399

Fleet Forum. (2019). Fleet Forum: Understanding Total Cost Of Ownership. Retrieved from https://knowledge.fleetforum.org: https://knowledge.fleetforum.org/knowledgebase/article/understanding-total-costs-of-ownership

FleetEurope. (2021, 4). The Flexible Fleet For An Optimised Efficieny. Retrieved from www.fleeteurope.com: https://mcusercontent.com/49deb4e88e1caa22d53f38cef/files/7d1e4903-2386-419a92caab0cc995b15d/Nexus_FEU122_web.pdf?utm_source=Fleet+Europe+Newsletter\&utm_c ampaign $=\mathrm{e} 2 \mathrm{~b} 29064 \mathrm{fa}-$

EMAIL_CAMPAIGN_2019_09_23_FEU109_COPY_01\&utm_medium=email\&utm_ter $\mathrm{m}=0 \_4128 \mathrm{e} 0 \mathrm{~d} 88 \mathrm{f}-$

Foggia, G. D. (2021). Drivers and challenges of electric vehicles integration in corporate fleet: An empirical survey. Research in Transportation Business \& Management, 100627. doi:10.1016/j.rtbm.2021.100627

Frank Jacobs. (2021, April 20). Arval Mobility Observatory Fleet Barometer 2021: Fleets are more confident than before the pandemic. Retrieved from fleeteurope.com: https://www.fleeteurope.com/en/maas/europe/features/arval-mobility-observatory-fleetbarometer-2021-fleets-are-more-confidentpandemic? $=$ =FJA05\&t $\% 5 \mathrm{~B} 0 \% 5 \mathrm{D}=\mathrm{Arval} \% 20$ Mobility $\% 20$ Observatory \& $\mathrm{t} \% 5 \mathrm{~B} 1 \% 5 \mathrm{D}=\mathrm{El}$ ectrification \&t\%5B2\%5D=Mobility\%20budget\&curl $=1$

Gavronski, I., Klassen, R. D., Vachon, S., \& Nascimento, L. F. (2011, November). A resourcebased view of green supply management. Transportation Research Part E: Logistics and Transportation Review, 47(6), 872-885. doi:10.1016/j.tre.2011.05.018

GlobalFleet. (2017, February 6). GlobalFleet. Retrieved from globalfleet.com: https://www.globalfleet.com/fr/financial-models-new-energies-taxation-andlegislation/europe/features/car-cost-varies-eu344month?a=FJA05\&t\%5B0\%5D=LeasePlan\&t\%5B1\%5D=Finance\&t $\% 5 \mathrm{~B} 2 \% 5 \mathrm{D}=$ Mobilit y\%20budget\&t $\% 5 \mathrm{~B} 3 \% 5 \mathrm{D}=\mathrm{TCO} \& \mathrm{curl}=1$

GlobalFleet. (2019, November 12). GlobalFleet. Retrieved from globalfleet.com: https://www.globalfleet.com/fr/fleet-strategy/europe/analysis/revisiting-basics-ifmi2019? $\mathrm{a}=$ YHE11\&t\%5B0\%5D=IFMI\%20Masterclass\&t\%5B1\%5D=Fleet\%20Europe\%2 0Summit\&curl=1

GlobalFleet. (2020, May 19). GlobalFleet Turkey. Retrieved from globalfleet.com: https://www.globalfleet.com/en/wikifleet/turkey

Goldman, T., \& Gorham, R. (2006). Sustainable urban transport: Four innovative directions. Technology in Society, 28, 261-273. doi:10.1016/j.techsoc.2005.10.007

Gorrie, P. (2013). Greening the FleetAuthor(s). Corporate Knights Inc., 12(1), 26-29. Retrieved from https://www.jstor.org/stable/26789163

Copyright (C) 2020, Journal of Advanced Research in Economics and Administrative Sciences (JAREAS), Under a 
Grayson, E., \& Kjelleren, G. (2015). The Business Case for Environmental Sustainability. Business Law Today, 1-5. Retrieved March 16, 2021, from www-jstororg.lproxy.yeditepe.edu.tr/stable/businesslawtoday.2015.01.04

Hart, S., \& Milstein, M. (2003). Creating sustainable value. Academy of Management Executive, 17(2), 56-69.

Henriques, I., \& Sadorsky, P. (1996, May). The Determinants of an Environmentally Responsive Firm: An Empirical Approach. Journal of Environmental Economics and Management, 30(3), 381-395. doi:10.1006/jeem.1996.0026

Hermundsdottir, F., \& Aspelund, A. (2021, January). Sustainability innovations and firm competitiveness: A review. Journal of Cleaner Production, 280(1), 1-18. doi:10.1016/j.jclepro.2020.124715

Hetterich, J., Bonnemeier, S., Pritzke, M., \& Georgiadis, A. (2012, April 4). Ecological sustainability - a customer requirement? Evidence from the automotive industry. Journal of Environmental Planning and Management, 55(9), 1111-1133. doi:10.1080/09640568.2011.636578

Hsu, C., Tan, K., Zailani, S., \& Jayaraman, V. (2013). Supply chain drivers that foster the development of green initiatives in an emerging economy. International Journal of Operations \& Production Management, 33(6), 656-688. doi:10.1108/IJOPM-10-20110401

IndustryWeek. (2107, May 26). IndustryWeek. Retrieved from https://www.industryweek.com: https://www.industryweek.com/technology-and-iiot/energy/article/22017905/electriccars-soon-will-cost-less-than-gasoline-autos-research-shows

Jenny Shiner . (2017, October 16). Construction Business Owner. Retrieved from Your Fleet Is a Key Factor in Marketing: https://www.constructionbusinessowner.com/marketing/yourfleet-key-factor-marketing

Küçükoğlu, M. T., \& Pınar, İ. R. (2018, 4 20). THE MEDIATING ROLE OF GREEN ORGANIZATIONAL CULTURE BETWEEN SUSTAINABILITY AND GREEN INNOVATION: A RESEARCH IN TURKISH COMPANIES. BUSINESS \& MANAGEMENT STUDIES: AN INTERNATIONAL JOURNAL, 6(1), 64-85. doi:10.15295/bmij.v6i1.208

Labuschagne, C., Brent, A., \& van Erck, R. (2005). Assessing the sustainability performances of industries. Journal of Cleaner Production, 13(4), 373-385. doi:10.1016/j.jclepro.2003.10.007

Law, K. M., \& Gunasekaran, A. (2012). Sustainability development in high-tech manufacturing firms in Hong: Motivators and readiness. International Journal of Production Economics, 137(1), 116-125. doi:10.1016/j.ijpe.2012.01.022

LeasePlan. (2017). 2017 LeasePlan whitepaper sustainable fleet management. Retrieved from www.leasepan.com: https://www.leaseplan.com/-/media/leaseplandigital/ix/documents/2017-leaseplan-whitepaper-sustainable-fleet-management.pdf

LeasePlan. (2017). LeasePlan Sustainability Report. Retrieved from www.leaseplan.com: https://www.leaseplan.com/corporate/ /media/Files/L/Leaseplan/documents/leaseplansustainability-report-2019-v1.pdf

Litman, T., \& Burwell, D. (2006). Issues in sustainable transportation. International Journal of Global Environmental Issues, 6(4), 331-347.

Copyright (C) 2020, Journal of Advanced Research in Economics and Administrative Sciences (JAREAS), Under a Creative Commons Attribution 4.0 International License 
Lois, A. M., Deborah, J. W., \& Katherine, E. H. (2001). Do Consumers Expect Companies to be Socially Responsible? The Impact of Corporate Social Responsibility on Buying Behavior. The Journal of Consumer Affairs, 35(1), 45-72. doi:https://doi.org/10.1111/j.1745-6606.2001.tb00102.x

Malacarne, Eleonora. (2015, February 7). Driving for work and corporate responsibility. Retrieved from Transpoco Telematics: https://www.transpoco.com/blog/2015/02/07/driving-work-corporate-responsibility/ Malacarne, Eleonora. (2018, May 17). Tips on Fleet Management, Fuel Management, Best Practice Driving and Safety for Your Employees. Retrieved from Transpoco Telematics: https://www.transpoco.com/blog/corporate-social-responsibility-how-do-fleets-manage-it

Marchet, G., Melacini, M., \& Perotti, S. (2014). Environmental sustainability in logistics and freight transportation: A literature review and research agenda. Journal of Manufacturing Technology Management, 25(6), 775-811. doi:10.1108/JMTM-06-2012-0065

May, A. D., Page, M., \& Hull, A. (2008). Developing a set of decision-support tools for sustainable urban transport in the UK. Transport Policy, 15(6), 328-340. doi:10.1016/j.tranpol.2008.12.010

McGill. (2013). mcgill.ca. Retrieved from mcgill.ca/sustainability/what-is-sustainability. Monnerat, F., Dias, J., \& João Alves, M. (2019). Fleet management: A vehicle and driver assignment model. European Journal of Operational Research, 278(1), 64-75. doi:10.1016/j.ejor.2019.03.021

Nakamura, M., Takahashi, T., \& Vertinsky, I. (2001, July). Why Japanese Firms Choose to Certify: A Study of Managerial Responses to Environmental Issues. Journal of Environmental Economics and Management , 42(1), 23-52. doi:10.1006/jeem.2000.1148

Nunes, B., \& Bennet, D. (2010). Green operations initiatives in the automotive industry: An environmental reports analysis and benchmarking study. An International Journal, 17(3), 396-420. doi:10.1108/14635771011049362

Preble, T. L. (1953). Fleet Management: A Job Evaluation. SAE Transactions, 61(1953), 273278.

Reinhardt, F. L. (1998, July 1). Environmental Product Differentiation: Implications for Corporate Strategy. Californina Management Review, 40(4), 43-73. doi: $10.2307 / 41165964$

Rodrigo, L. (2015). A holistic perspective on corporate sustainability drivers. Corporate Social Responsibility and Environmental Management, 22(1), 32-44.

Sarah Tooze. (2013, 1 10). Insight: Corporate social responsibility. Retrieved from Fleet News: https://www.fleetnews.co.uk/fleet-management/insight-corporate-socialresponsibility/45870/?p=4

Schöggl, J.-P., Baumgartner, R. J., \& Dietmar, H. (2016). Improving sustainability performance in early phases of product design: A checklist for sustainable product development tested in the automotive industry. Journal of Cleaner Production, 140(3), 16021617. doi:10.1016/j.jclepro.2016.09.195

Singh, A., Gurtu, A., \& Singh, R. K. (2020). Selection of sustainable transport system: a case study. Management of Environmental Quality, 32(1), 100-113.

Copyright (C) 2020, Journal of Advanced Research in Economics and Administrative Sciences (JAREAS), Under a Creative Commons Attribution 4.0 International License 
Sungchul, C., \& Ng, A. (2011, May 26). Environmental and Economic Dimensions of Sustainability and Price Effects on Consumer Responses. Journal of Business Ethics, 269-282. doi:https://doi.org/10.1007/s10551-011-0908-8

Szasz, L., Csiki, O., \& Racz, B.-G. (2021, March 1). Sustainability management in the global automotive industry: A theoretical model and survey study. International Journal of Production Economics, 235, 1-14. doi:10.1016/j.ijpe.2021.108085

Tagliapietra, S., \& Zachmann, G. (2018, April 1). ADDRESSING EUROPE'S FAILURE TO CLEAN UP THE TRANSPORT SECTOR. Retrieved 3 11, 2021, from Bruegel: https://www.jstor.org/stable/resrep28617?seq=1\#metadata_info_tab_contents

Teresa, D., Ferreira, L. P., Silva, F., \& Tjahjonoc, B. (2020, November 19). Open Innovation and Sustainable Development through Industry-Academia Collaboration: A Case Study of Automotive Sector. Procedia Manufacturing, 51, 1773-1778. doi:10.1016/j.promfg.2020.10.246

Thun, J.-H., \& Müller, A. (2010). An Empirical Analysis of Green Supply Chain Management in the German Automotive Industry. Business Strategy and the Environment, 19, 119-132. doi:10.1002/bse.642

Tokgöz, N., \& Önce, S. (2009). Corporate sustainability: alternative approach to traditional business management. Afyon Kocatepe Üniversitesi İ̈BF Dergisi, 11(1), pp. 249-275.

Turker, D., \& Altuntaş, C. (2014). Sustainable supply chain management in the fast fashion industry: An analysis of corporate reports. European Management Journal, 32(5), 837849. doi:10.1016/j.emj.2014.02.001

Wei, Y. (., \& Morgan, N. A. (2004, October 22). Supportiveness of Organizational Climate, Market Orientation, and New Product Performance in Chinese Firms. Journal of Product Innovation Management, 21, 375-388. doi:10.1111/j.0737-6782.2004.00092.x

Wong, L. T., \& Fryxell, G. E. (2004). Stakeholder Influences on Environmental Management Practices: A Study of Fleet Operations in Hong Kong (SAR), China. Transportation Journal, 43(4), 22-35.

Zhou, K. Z., Brown, J. R., \& Dev, C. S. (2009, November 8). Market orientation, competitive advantage, and performance: A demand-based perspective. Journal of Business Research, 62(11), 1063-1070. doi:10.1016/j.jbusres.2008.10.001

Zhu, Q., Sarkis, J., \& Lai, K.-h. (2013). Institutional-based antecedents and performance outcomes of internal and external green supply chain management practices. Journal of Purchasing and Supply Management, 19(2), 106-117. doi:10.1016/j.pursup.2012.12.001

Copyright (C) 2020, Journal of Advanced Research in Economics and Administrative Sciences (JAREAS), Under a 